DOI: 10.2478 /ausfm-2014-0031

\title{
Embodied Genetics in Science-Fiction, Big-Budget to Low-Budget: from Jeunet's Alien: Resurrection (1997) to Piccinini's Workshop (2011)
}

\author{
Andrea Virginás \\ Sapientia Hungarian University of Transylvania (Cluj-Napoca, Romania) \\ E-mail: avirginas@gmail.com
}

\begin{abstract}
The article uses and revises to some extent Vivian Sobchack's categorization of (basically) American science-fiction output as "optimistic big-budget," "wondrous middle-ground" and "pessimistic low-budget" seen as such in relation to what Sobchack calls the "double view" of alien beings in filmic diegesis (Screening Space, 2001). The argument is advanced that based on how diegetic encounters are constructed between "genetically classical" human agents and beings only partially "genetically classical" and/or human (due to genetic diseases, mutations, splicing, and cloning), we may differentiate between various methods of visualization (nicknamed "the museum," "the lookalike," and "incest") that are correlated to Sobchack's mentioned categories, while also displaying changes in tone. Possibilities of revision appear thanks to the later timeframe (the late 1990s/2000s) and the different national-canonical belongings (American, Icelandic-GermanDanish, Hungarian-German, Canadian-French-American, and Australian) that characterize filmic and artistic examples chosen for analysis as compared to Sobchack's work in Screening Space. ${ }^{1}$
\end{abstract}

Keywords: science-fiction, genetic mutations, aliens, Vivian Sobchack.

\section{Hero(ines) Facing Genetic Aliens}

In her exceptional monograph about modern American science-fiction cinema, Screening Space (2001), Vivian Sobchack writes in detail about "the alien's perspective," the creature that not only is different from us, but, as a matter of fact, cannot be conceived of from the standpoint we, humans, occupy, neither

1 This work was supported by a grant of the Romanian Ministry of Education, CNCS UEFISCDI, project number PN-II-RU-PD-2012-3 - 0199. 
theoretically, nor visually, even if this is an urge at the core of the genre of science fiction. ${ }^{2}$ The endless meaning and appearance possibilities of the "classical alien" have been undergoing a process of change due to biological and technological developments in the last several decades. These developments can be summarized under the keywords of the genetic and the digital, and may be exemplified with concepts and figures such as the DNA, the process of cloning, and the idea of genetic inheritance, the latter leading to the concept of networks, and copies that are hardly different from the original. When referred to the audiovisual filmic diegesis, one must highlight the fact that both the territories of the genetic and the digital are "closed" to the five basic human senses: seeing, hearing, smelling, tasting, and touching. This constellation leads to specific methods, solutions and outcomes concerning the genetic and the digital's introduction as well as representation within particular filmic diegeses.

Sobchack devotes particular attention to how what she calls "the reduction of humanistic perception" or "the expansion of perception beyond the human" is instrumentalized on the level of cinematic solutions. A propos the alien's "double view" - both their view on us, humans, but also our view of them she differentiates between three types of science fiction films: "big-budget optimistic," "low-budget pessimistic," and "wondrous" middle-ground films. She writes the following, starting with the description of "an impassive thirdperson camera-eye" present in one of her examples: "the impassive third-person camera eye, in its flatness, its balanced and symmetrical attention to both the real and the imaginary, creates a wonder which is unique. It arises not from the visual transformation of the alien into something known as does the optimistic visual conquest of the big-budget science fiction film. Nor does it arise from the conversion of the ordinary into the alien as does the pessimistic visual subversiveness of low-budget science-fiction. Rather this third group of muchmaligned SF film balances and equates the ordinary and the alien in a vision neither humanly optimistic nor pessimistic. [...] What is unique about this last group of SF films is that its visual style demonstrates simultaneously both the unremitting banality and the inconceivable terror" (Sobchack 2001, 144-45).

2 In Sobchack's formulation “the major visual impulse of all SF films is to pictorialize the unfamiliar, the nonexistent, the strange and the totally alien - and to do so with a verisimilitude which is, at times, documentary in flavour and style. [...] To make us believe in the possibility, if not probability, of the alien things we see, the visual surfaces of the films are intextricably linked to and dependent upon the familiar; from the wondrous, and strange and imagined, the cameras fall back on images either so familiar they are often downright dull, or neutralize the alien by treating it so reductively that it becomes ordinary and comprehensible” (Sobchack 2001, 87-88) 
These two directions of thought presented by Sobchack - the alien's "double view," as well as the three types of science fiction films deduced from various cinematic depictions involving the alien - are fundamental for the present article. Its argumentation engages in analysing the "double view" of genetically defined and, in many cases, digitally created aliens in various contemporary (1990s/2000s) films and artworks, ranging from "big-budget optimism" (Jeunet's 1997 Alien: Resurrection) (on) to "wondrous middle-ground" (Natali's 2009 Splice, Kormákur's 2006 Jar City) and ending with the "low-budget pessimist" side of the continuum (Fliegauf's 2010 Womb or Piccinini's 2008 Foundling and The Fitzroy-series). The basic unity of analysis, engendered by the idea of a genetic and digital alien's "double view," are first encounters in diegetic (also, in most of the cases, closed) spaces, of such human heroes and genetically modified aliens who share some of their DNA (a science-fiction narrative), and if not, then intense (and positive) emotional investment on the part of the humans is present (a detection narrative).

The last part of the Alien-series to date, ${ }^{3}$ the 1997 Alien: Resurrection, was directed by French filmmaker Jean-Pierre Jeunet. He has been manifesting a keen interest for fantastic environments and plots in his films: the movie preceding Alien: Resurrection was The City of Lost Children in 1995, and the one following it was Le fabuleux destin d'Amelie Poulain in 2001. However, the Alien-sequel is a singular foray on Jeunet's part - the popular French director more on the arthouse side - into big-budget, optimistic science-fiction.

In Alien: Resurrection Ellen Ripley is cloned to life in an outer space laboratory in order to offer an adequate linkage to well-known aliens, who subsequently are also cloned and bred in the hope of industrial-commercial exploitation. Ripley is as agile as ever, and several of her interactions with the environment around (throwing a basket-ball, thrusting a nail through her hand) early in the film suggest that she possesses capacities miraculous for a simple human being. The specific sequence I am quoting here follows the moment when she joins the band of illegal pirates and, being the last ones on the space station invaded by the ferocious aliens, they are trying to embark on the spaceship. A door and the numbers on them (1-7) attract Ripley's attention, since she has a number eight tattooed on her arm, and she enters through the door alone, while the others are proceeding.

This space could be called the museum gallery of further Ripley-clones on display [Fig. 1], clones which have gone wrong in the process of mixing human and alien DNA, actually the process of making the new type of Ripley while

3 Unless we consider Ridley Scott's 2012 Prometheus as a variation on the same theme. 
cloning to life her DNA already "infected" with the alien DNA. ${ }^{4}$ The different Ripley/alien versions are shown standing in cylindrical glass jars full of greenish transparent amniotic liquid, in which the various hybrid bodies float, seem to be sleeping, or secluded from onlookers and the outside world, and thus Ripley also, even though earlier versions of her body and herself. The climactic point of the scene is her coming face to face with the painfully living and suffering being no. 7 [Fig. 2], who has Ripley's face, but the alien's legs, and who, quite inadequately, is showing embarrassment because of two reasons: 1. she is uncovered, and she has to protect her modesty; 2. she is experiencing extreme pains, the pains of existing in-between bodies and species. Samuel A. Kimball comments on the scene thus: "An incoherent assemblage of parts that are not viable on their own, this corporeal frame nevertheless houses, imprisons rather, a self-reflexive consciousness. [...] Approaching the suffering creature without a word, Ripley, fighting back tears, touches the sheet that partially covers her" (Kimball 2002, 97-98). According to the conventions of action science-fiction, after a moment of empathy, the sequence ends with Ripley shooting clone number 7, at her request.

Another important moment, in its construction similar to Ripley's entering the hall of her "abortive clones" (Kimball's expression), is to be found in Icelandic director Baltasar Kormákur's 2006 genetic detection movie, Jar City (Mýrin). Here, the morose, lonely detective, Erlendur, enters a medical laboratory where formerly ill body parts are being kept in formalin [Fig. 3]. He is guided by the genetic database researcher, Örn, whose daughter also died because of the secretly transmitted genetic disease (neurofibromatosis) that is the trace and key to the murders Erlendur, the detective is investigating. The mise-en-scène and choreography is similar to the one in Alien: the self-sufficient and confident human being enters a closed space of exhibition, where the differently shaped glass jars contain genetically wrong, non-perfect, problematic versions of former human beings and/or their earthly remains. I wish to direct our attention to the moment of encounter between the detective and the genetically problematic brain on display [Fig. 4]: touch and close observation are repeatedly in the choreography. Erlendur takes from the shelf the jar containing the child brain infected with neurofibromatosis, and the slowly constructed series of movements, the half-light glittering through and on the glasses around, as well as Erlendur's pensive mimics suggest a peaceful atmosphere adequate for contemplation rather than fright or disgust because of the genetically "other."

$4 \quad$ By which she was already inhabited at the time of her death in the previous part of the tetralogy. 
Hungarian director Benedek Fliegauf's 2010 Womb places the narrative about genetic cloning (understood as "an anomaly in the genetic story") in an arthouse environment, from where only the "Venus-like figure" of actress Eva Green stands out as a "suspect," transtextually and generically much too loaded body of/for signification. She plays the role of a single mother who gives birth to her dead lover through the technology of cloning, a lover who thus becomes her son. Here I wish to recall the scene when children smell out "the plastic smell" of one of their mates, who is also a clone, a fabricated child [Fig. 5]. Rebecca, the mother, Thomas, her (secretly cloned) son, his comrade and the utterly fabricated girl are the protagonists: they all meet on a clearing in the forest and a small discussion takes place, ending with the verdict that the skin of copied (aka: cloned) individuals "smells like window-cleaner." Here, the visualization of genetic anomaly is suppressed if compared to the previously summarized sequences: there is no bell jar full with experiments intended by researchers or accidental by nature. The alien and non-fitting nature of the clone is signalled through the mother's bewilderment as wonderfully played by Eva Green's gestures and mimics [Fig. 6], furthermore the paleness of the little girl's skin and hair, as opposed to her environment, and finally the long take of her vanishing figure, with all the other characters shown in medium shots [Fig. 7].

Moving on with the introduction of the examples, most of Australian artist Patricia Piccinini's works are exclusively dedicated to imagining and representing creatures of mixed ancestry and DNA, ${ }^{6}$ although not within the discourse of science fiction cinema, but that of museum and gallery art. She uses techniques such as hyperrealist sculpture (the famous 2008 Foundling [Fig. 8]), classical drawings in pencil [Fig. 9], and digitally manipulated photographs [The Fitzroy series from 2011]). These certainly function much differently than the immersive feature film, the narrative recipe of which is well known, a recipe which in

$5 \quad$ These are the words of actor Johnny Depp, characterizing Eva Green in an interview published in the Hungarian national daily Népszabadság on May the $19^{\text {th }} 2012$.

6 This endeavour makes Piccinini's highly conceptual and perceptually rather stimulating artworks resemble, or indeed join such computer simulations that belong to the Artificial Life strand of theoretical biology: "Langton, in his explanation of what AL can contribute to theoretical biology, makes this difference explicit: Artificial Life is the study of man-made systems that exhibit behaviors characteristic of natural living systems. It complements the traditional biological sciences concerned with the analysis of living organisms by attempting to synthesize life-like behaviours within computers and other artificial media. By extending the empirical foundation upon which biology is based beyond the carbon-chain life that has evolved on Earth, Artificial Life can contribute to theoretical biology by locating life-as-we-know-it within the larger picture of life-as-it-could-be" (Hayles 1999, 232). 
the case of Piccinini's works is replaced by still images showing contexts and situations. In these contexts and situations beings and objects visibly human are involved and interact with bodies and life-forms that are the visualizations of different types of DNA being mixed, cloned, and spliced together. The Workshop piece of the Fitzroy series [Fig. 10] is especially important in the light of my last example listed below, as an always already "double view" of the alien defined in the relationship to the human: here, in a barely lit, closed and messy place a nice young girl peacefully waits while a non-classifiable, alien body is searching or looking into a bin [Fig. 10].

The last example is Canadian director Vincenzo Natali's Splice (2009), in which the experimental genetic scientist, Elsa (played by Sarah Polley) makes the first encounter and as she calls it, imprinting (making friendship) with the being that is combining her own DNA with further animal DNA segments [Fig. 11]. The creature, later calling herself Dren, is simultaneously the experimenting woman scientist herself, also her daughter, but her radical, fundamental other too: the alien in this sequence allows for Elsa's being circumscribed as a potent and active woman scientist. The scene is the laboratory, again, and what we witness, on a conceptual level, is a moment of connection between genes as working in a standard manner, creating humans (in the form of Elsa), and genes as contributing to the creation of clones and hybrids (in the form of future Dren).

Sobchack mentions that subjective camera shots related to alien forms are relatively rare in sci-fi films, even if this technique would allow us, viewers to identify with perceptional modes different from the perceptional modes assigned to human subjective shots in sci-fi films (Sobchack 2001, 93). In my examples, such subjective shots that would de-familiarize one's routine modes of perception are not present either, and this may be motivated by the fact that the represented genetic variations (whether mutant, clone, or hybrid) may be considered only partially "classical aliens," since the films' narratives make it obvious that the human input or factor is always and already there. Thus the examples mentioned from Alien: Resurrection, Jar City, Womb, Splice and Foundling/The Fitzroy Series materialize and theorize upon border experiences, and I argue that their chief preoccupation is not defining (in a negative cutting manner) what it means to be a human, or how we can conceive, represent, and sense truly aliens life forms in environments of artificial representation, be that moving image or digital photography, sculpture or drawing, following in Sobchack's steps. Instead, these examples offer us the occasion to meet and meditate upon degrees of humanity and alienness involved. These films also create contexts and use conventions that guide us, as participants 
in the spectacle, while reacting and adapting to beings that are not fully, but only partially different from what a human being is on the screen.

The examples included in the analysis dramatize encounters between the chief heroes, decipherable as the entities that gather our maximum interest, emotional and bodily investment as they exist and move through highly dangerous spaces and contexts, and the genetic variations. These variations are as diverse as a brain with the trace of genetic hereditary disease (long dead little Aude's brain and neurofibromatosis in Jar City), clone-variants of the hero's own body and identity (Ripley meeting clones numbered 1-7, each a stage closer and closer to her as an admired and perfect human-alien hybrid), the clone as the mirror-image of one's child (Rebecca and little Deema's forest meeting), or the hybrid clone who amalgamates one's very own biological and psychic/emotional characteristics, being at once the investigative heroine and the truly different (Elsa and Dren's first meeting), and finally the fully alien incorporated, included into the emotional and representational harmony in Piccinini's differently coded works.

\section{Degrees of Visualization: Museums, Lookalikes, and Incests}

As my examples have illustrated, a number of recurring methods of representation may be suggested: the museum of genetic aliens, encounters with genetic aliens, superficially similar genetic aliens, and finally interiorized genetic aliens.

The museum of genetic aliens offers us the genetically modified body on display in bell jars, recreating the context of museum visit, when the seeing and experiencing subject is moving and sensing artistic objects on display. Demands of interactivity are accomplished as the investigating heroes touch, caress, or take into their hands the clones and genetically ill body parts. This category reminds us of how Vivian Sobchack describes what she sees as a successful visualization of alien life forms, existing "most potently on the screen in a state of suspension, of pregnant possibility:" "If the totally imaginative visualizations of alien life forms in the sci-fi film strive to dislocate us from the narrow confines of human knowledge and human experience, they best do so when they are virtually silent and primarily inactive. [...] To give such imaginative visual realizations voice and function is to make them comprehensible and reduce their awesome poetry to smaller human dimensions; they exist most potently on the screen in a state of suspension, of pregnant possibility, of potential rather than realized action" (Sobchack 2001, 92). 
Another method is that of the genetically modified body shown as moving and counteracting with the hero(ine)s, as in the laboratory sequence of Splice or in Piccinini's Workshop, or indeed the end of the Alien-sequence. Here the same and familiar spatial arrangement is present, and the profoundly empathetic turn of the active, watching heroines to the genetically different bodies and life forms resumes to a degree (from) the foreign and monstrous nature of the genetic variants. However, one cannot help but notice the gradual assimilation of the self/the human identity by the alien form in movement. In the sequences from Alien: Resurrection and Splice, and also the photograph from The Fitzroy series the body postures, gestures, and approaches of bodies built from human DNA and bodies based on mixed/alien DNA mirror, reflect and copy each other, suggesting the gradual assimilation of genetically standard forms of being to genetically non-standard ones. Katherine N. Hayles's observation a propos genetic mutation is illuminating in this respect: "Mutation normally occurs when some random event (for example, a burst of radiation or a coding error) disrupts an existing pattern and something else is put in its place instead. Although mutation disrupts pattern, it also presupposes a morphological standard against which it can be measured and understood as a mutation. If there were only randomness, as with the random movements of gas molecules, it would make no sense to speak of mutation" (Hayles 1999, 32-33).

In the third case, the genetically modified body is not having striking outer differences as demonstrated by the sequence in Fliegauf's Womb, a feature that also originates from the film's arthouse discursive belonging and nonemployment or tacit employment of digital special effects. Here, the alien tissue is materialized in conversations, aka linguistic signs and concepts, and also through perceptional experiences of the characters on screen (in this case, smelling), not easily transmittable to the audience unless a strong identification with the sensing hero is achieved. Furthermore, conventional and (film historically and poetically) realistic audiovisual modes of signalling unfamiliarity are employed: colour and object differences - little Deema, the clone's extreme fairness, highlighted by the symbolically overloaded white rabbit she has in her arms [Fig. 12] -, and also strongly resonating visual composition. One may cite further recent examples where alienness (partially motivated by genetically transmitted diseases or inexplicable, supposedly genetic mutations) is not allegorically represented by spectacular audiovisual symbols: the character of Justine in Lars von Trier's 2011 Melancholia, the representation of the gradual loss of sensual capacities in David MacKenzie's 2011 Perfect Sense, or the introduction of a 
science fiction narrative in a filmic representation realistic in every sense in Mike Cahill's Another Earth (2011). ${ }^{7}$

Finally, Womb and Splice, which achieve the greatest outer similarity in the representation of clones and humans, also offer solutions that seem extreme at first sight since the otherness of the genetic anomalies is creeping in the bodies of the active observer heroes too. This is the case of the smell of plastic in $W o m b$, furthermore a different version of this interiorizing happens when the genetic anomaly is not located in the form of an alien body and its differing modes of behaviour, but it "moves" inside the body - in the form of incestuous relationships represented in the narratives of the films. Both in Womb and Splice, the genetically aliens are at once clones and children of the main heroines, beings that mature (extremely rapidly) so that the viewers are offered the possibility to witness incestuous intercourses between mother Rebecca and son Thomas in Womb, or mother Elsa and daughter/son Dren in Splice.

However, on a closer look, this "interiorizing of alienness" ceases to be an extreme narrative and moral solution, and emerges as a logical outcome of the cloning procedure that gives birth to new beings without sexual-type reproduction involved, with the procedure of cloning (aliens) equalling the ignorance of sexuality as a human cultural invention. Since, as Petar Ramadanovic clearly demonstrates in his paper based on Claude Lévi-Strauss, "the incest prohibition is not only a cultural norm. As a prohibition, it is also a function that makes culture possible. The taboo is the invention upon which the notion of culture [...] rests. [...] the taboo is not only, or primarily, a particular rule banning sex with the nuclear family, it is a 'taboo,' a fundamental rule that makes sexuality" (Ramadanovic 2010, 13-14). As a matter of fact, Piccinini's cited works could be referred to as a context where the stigmas of disease and incest disappear, leaving room for visually interesting, enhanced bodily and instinctual capacities depicted. In this respect we may cite the artist's 2011 Statement referring to The Fitzroy Series as an argument. "My creatures," Piccinini declares, "while strange and unsettling, are not threatening. Instead, it is their vulnerability that often most comes to the fore. They plead with us to look beyond their unfamiliarity, and ask us to accept them. It is surprising how quickly we grow used to them, which reminds us that this sort of thing is not as far in the future as we might think."

7 These surface differences, if completed by rigorous textual, formalist, narrative, and iconographic analyses, would allow one to speak about a "mutation" in contemporary science-fiction, where arthouse, European-type, or American independent filmic characteristics are being mixed (hybridized?) with mainstream science-fiction features. 


\section{Conclusions: Bodies, DNA, and Canons}

Visual genres in the science-fiction tradition are intensely engaged in conceptualizing "classical," genetically unproblematic human beings in the company of beings that are different because of genetic anomalies, changes, and hybrizations. Thus the nature and process of interaction(s) that happen(s) between human and alien, or standard "human" DNA and non-standard "alien” DNA is highlighted. This preoccupation does not belong exclusively to the big-budget spectacular blockbuster, where artificial CGI design does the work of imagining all kinds of beings and life-forms not seen up to now (and here we may think of the flora and fauna, or indeed the Na'avi population in James Cameron's 2010 Avatar). Lower-budget science fiction, also differentiated by Sobchack as more conceptually engaged than simply visually effective, post Space Odyssey and Stalker, is also involved in this project and one chief method in this respect is the one that the scenes chosen for examination represent. In these sequences the active protagonist - the figure of main spectatorial identification in the actiondriven narratives - is put in a contemplative situation by entering a space of (laboratory) exhibition and forced, knowingly or unintentionally, to exist in the company of genetic anomalies, hybrids, and mutants. Furthermore, it is not only the reactions, or mode of play of the actors that guide our attitudes while living through these scenes, but the dynamics, choreography and spatial structuring of the scenes are also of a paramount importance. It is important to emphasize that these are diegetic encounters between the active heroes and the anomalous bodies, encounters that therefore might lay claim to such affects being played out and felt as empathy, understanding and even sympathy - thanks to the mutual mirroring poses, gestures, and mimics acted out and represented in the compositional structures of the images as scenes. In this manner, room is created for what Vivian Sobchack refers to as the sensation of "living a body," in this specific case living a body partially, but not fully alien to us, humans: "The focus here is on what it is to live one's body, not merely to look at bodies - although vision, visuality, and visibility are as central to the subjective dimension of embodied existence as they are to its objective dimension” (Sobchack 2004, 2).

As the title also shows, this article uses the notion of embodiment in the most literal sense of the word: having a body, and living through and thanks to that body, a body which may be shown, heard, smelt, or touched in the audiovisual environment surrounding figurative representation. Bodies in question, however, are not real bodies in the sense of having corresponding referents in a material reality 
existing in the pre- or postproduction period of the creations they inhabit: they are not bodies of human or animal beings shot for the sake of films and photographs, or captured in drawings. These bodies are fully and totally fictional, so to say, existing only within the conventions of the respective figurative representations. However, the bodies I have made reference to are, at the same time, radically related to flesh-and-bone existence as we know it, being theoretical extensions of scientific possibilities constantly experimented and researched in connection to the human and animal body. In other words, these bodies (or body parts) are realisations of such biologically possible, yet currently either non-existent or hardly perceivable and/or sensible (i.e. non-embodied) concepts as hereditary genetic disease, offspring resulted from cloning rather than sexed reproduction, and finally hybrid beings that combine (splice) the genetic material of various biological entities (from humans on to animals). Certainly, by concentrating on the unique, these bodies that stand for hereditary genetic diseases, clones, and hybrid splices in the context of specific conventions of figurative representation - such as black-and white drawing in pencil, digital colour photography, science fiction movie, detection movie - may be called as looking for what is sensational, scary, not ordinary, or even disgusting to some extent.

Two opinions must be cited that have circumscribed and limited my ideas. In her 2007 book, The Poetics of DNA, Judith Roof is writing about all the burdens that have been put on the concept of DNA, and I quote her: "The three acronymic letters, then, like the chemical itself, have come to signify a vast number of processes, undifferentiated to the non-scientist and rendered intelligible by a series of metaphors or comparisons. These include such analogies as the 'secret of life,' the code, the book, the alphabet, sentences, words, chapters, histories, the Rosetta stone, the Holy Grail, the recipe, the blueprint, the text, the map, the homunculus, software, and others. None of these analogies is accurate in terms of how DNA works or even what it accomplishes. All of them import values, meanings, mechanisms, and possibilities that are not at all a part of DNA. The effect is that DNA has always stood for much more than what it is" (Roof $2007,7)$. In this respect, my reasoning about genetics and genetic concepts on screen - basically reducible to how the DNA and the gene are conceptualized through involving such dramaturgical and narrative lines as inheritance, cloning, splicing, as well as their audiovisualizations - is perhaps falling in the same trap of creating further, not too useful or enlightening metaphors and comparisons.

In an article about "the contemporary persistence of genetic thinking," Vesta da Silva is even more explicit about how the DNA and the gene, as abstract and 
non-sensible concepts, have nevertheless pervaded our realities full of sensations through the method of DNA fingerprinting. ${ }^{8}$ Da Silva, quoting a number of experts, also summarizes the situation when we tend to link identity, soul, and moral standpoint, one's past and future to the DNA a human body carries and is built up from: “'In many cases,” as Nelkin and Lindee $(1995,42)$ argued, 'DNA has taken on the social and cultural functions of the soul. It is the essential entity, the location of the true self, in the narratives of biological determinism.' As Gudding (1996, 545) explained, in the current deterministic paradigm, 'the truth of who someone is, forensically, medically, athletically, and otherwise, is to be found nearer to rather than farther from the genome' [...] If the contemporary moment is marked by fluidity, change, and fragmentation (or at least the perception that such qualities have overtaken us), it is comforting to know that our selfhood can be 'scientifically' assured. Science has succeeded in making visible what was once hidden - fixing for all time our ability to know and guarantee who and what we are." (Silva $2005,107$.

The second idea I have to foreground at this point of my argumentation and analysis belongs to Vivian Sobchack, who, in her book on American science fiction cinema, is extensively writing about how the invisible, unperceivable, or indeed alien life forms and their cinematic representation is at the heart of the genre. Quoting Sobchack: "On the most obvious level, the SF film attempts to meet our expectations by using the magic of design and special effects cinematography to show us things which do not exist, things which are highly speculative, which astonish us by the very fact of their visual realization on the screen since they have no counterparts in the world outside the theater. One can point to innumerable images in SF films which struggle - sometimes successfully, sometimes laughably-to exceed the anthropomorphic limits of the human imagination while still attempting to remain comprehensible" (Sobchack 2001, 91). Hopefully, the examples and the analysis have demonstrated that alienness and anthropomorphism are not opposed, but closely linked and interwoven, so this might generate a situation slightly different than the one described by Sobchack.

The motivations for such an endeavour have been manifold, also circumscribing the possible outcomes of the article. Besides proving the extreme viability of Sobchack's work written in the early 1980s (and first published in 1987), through a series of analyses performed on more recent examples and using her categories,

8 "Indeed, with the advent and acceptance of DNA fingerprinting, we set up a situation in which our genetic residue (left behind us wherever we go in the form of eyelashes, skin cells, etc.) has metonymically replaced our bodies as the ultimate seat of our identity" (Silva 2007, 106). 
the need to add corrections to her observations is also present. Such a need primarily derives from the fact that ours is a new era, pervaded by the digital and the genetic - a difference utterly visible if compared to the atomic and the exotic (monstrous) in abundance in the 1950s-1980s examples analyzed by Sobchack in her monograph. Also, a change in tone is discernible if compared to Sobchack's categorization: low-budget has become more optimistic and big-budget more pessimistic as far as genetically modified and digitally formed alien bodies encountered by "digitally classical" humans are concerned. Finally, because of shared grounds emphasized - grounds ranging from common DNA on to positive feelings and existing in the same room - the idea of alienness emerging from my analyses could be called "partial" in comparison to a "more total" variant presented by Sobchack.

In conclusion, we may state that in the action science-fiction film discourse (Alien 4 in my sample, but also The Matrix-trilogy), the "big-budget optimism" of Sobchack, the blending of human with alien (or human with machine) is not generated in the same manner and on the grounds of the same ideologies as in "more arthouse sci-fi" films such as Jar City, Womb, or Melancholia. In the latter "low-budget pessimistic" variant the incompatibility of different splices (or different-origin materials) is signalled through the methods (interpretable as metaphoric) of genetic bodily disease (Jar City), or (genetically transmitted) psychic instability disease (Melancholia), and incest (Womb, Splice). It is at this point that the discourses of genre and canon the movies in question rely on become important. These discourses either postulate the existence of a focalizer main hero(ine) who gathers the investment of the spectator, channelling the experience (feelings, thoughts) the viewer might have on human-alien-machine spliced organisms: this is what usually happens in the canon identified as the mainstream, classical-type storytelling of action science-fiction films. Or, on the contrary, these generic and canonical discourses may project a protagonist who divides, even to the point of senselessness, the psychic spectatorial investment, being founded on the more loose character-conventions of (European) arthouse films, with wandering, perhaps searching, aimless characters (of which Rebecca, Justine, and Piccinini's teenage girl may be examples). That, however, in most of the cases, it is female characters who need "the perform" on such dangerous terrains, evoking the script of un/successful maternal bonding with a newcomer offspring, attests to deep (perhaps even stereotypical) patterns at work, which may constitute the object of further investigation. 


\section{References}

Eleftheriotis, Dimitris. 2002. Global Visions and European Perspectives. In Aliens $R$ Us. The Other in Science Fiction Cinema, eds. Ziauddin Sardar and Sean Cubbitt, 164-180. London, Virginia: Pluto Press, 2002.

Katherine, N. Hayles. 1999. How We Became Posthuman: Virtual Bodies in Cybernetics, Literature and Informatics. Chicago \& London: University of Chicago Press.

Jameson, Fredric. 2005. The Alien Body. In Archaeologies of the Future. The Desire Called Utopia and Other Science Fictions, 119-141. London-New York: Verso.

Kimball, Samuel A. 2002. Conceptions and Contraceptions of the Future: Terminator 2, The Matrix, and Alien Resurrection. Camera Obscura vol. 17 no. 4 (50): 69-107. Piccinini, Patricia webpage, http://www.patriciapiccinini.net, accessed on the 15th of August 2014.

Ramadanovic, Petar. 2010. The Non-Meaning of Incest, or How Natural Culture Is. Postmodern Culture vol. 20 no. 2 (January): Project MUSE. http://muse.jhu. edu/ Last accessed at 27. 07. 2013.

Roof, Judith. 2007. The Poetics of DNA. Minneapolis-London: University of Minnesota Press.

Silva, Vesta T. 2005: In the Beginning Was the Gene: The Hegemony of Genetic Thinking in Contemporary Culture. Communication Theory vol. 15 no. 1 (February): 100-123.

Sobchack, Vivian. 2001 [1987]. Screening Space: The American Science Fiction Film. New York: Rutgers University Press.

Sobchack, Vivian. 2004. Carnal Thoughts. Embodiment and Moving Image Culture. Berkeley-Los Angeles-London: California University Press.

Telotte, J. P. 2001. Science Fiction Film. Cambridge: Cambridge University Press. 


\section{List of Figures}

Figure 1.The hall of Ripley-clones (Jean-Pierre Jeunet: Alien:Resurrection, 1997).

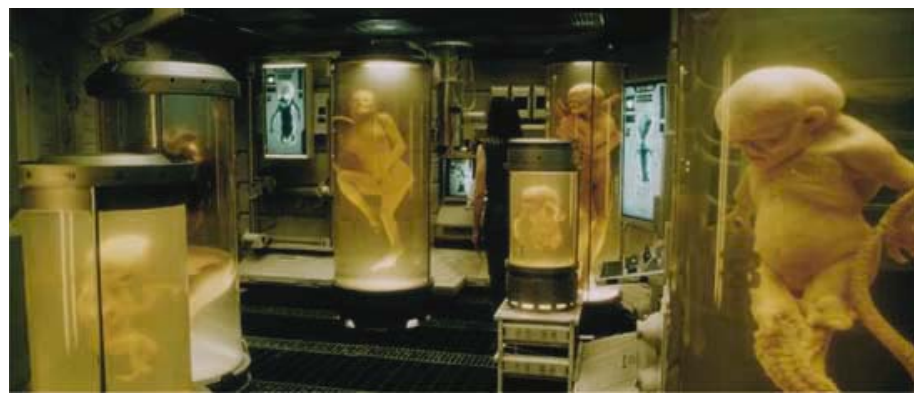

Figure 2. Ripley facing clone nr. 7 (Jean-Pierre Jeunet: Alien: Resurrection, 1997).

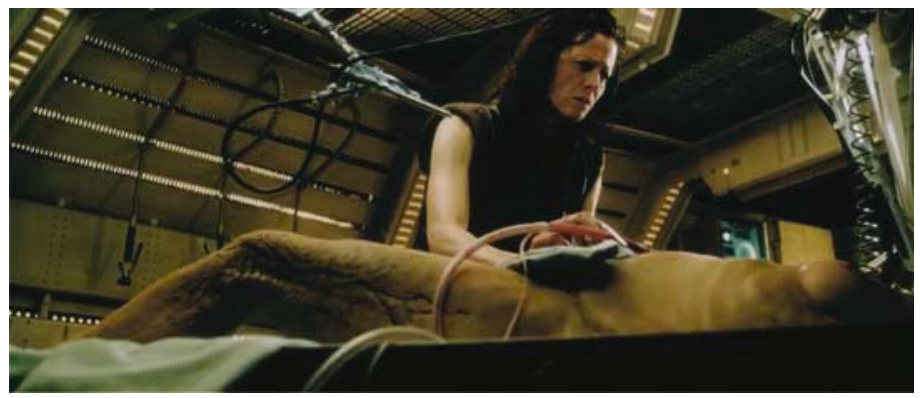

Figure 3. Genetic deviations on display (Balthasar Kormákur: Jar City, 2006).

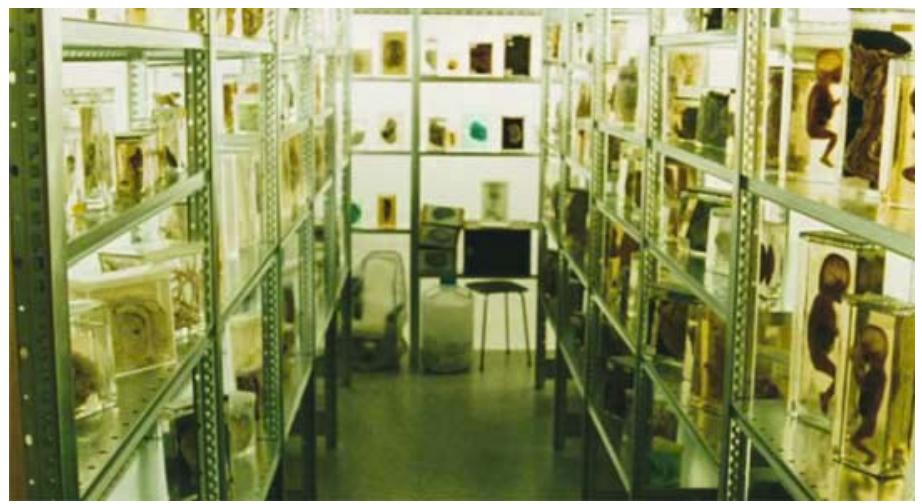


Figure 4. Örlendur looks at Aude’s brain (Balthasar Kormákur: Jar City, 2006).

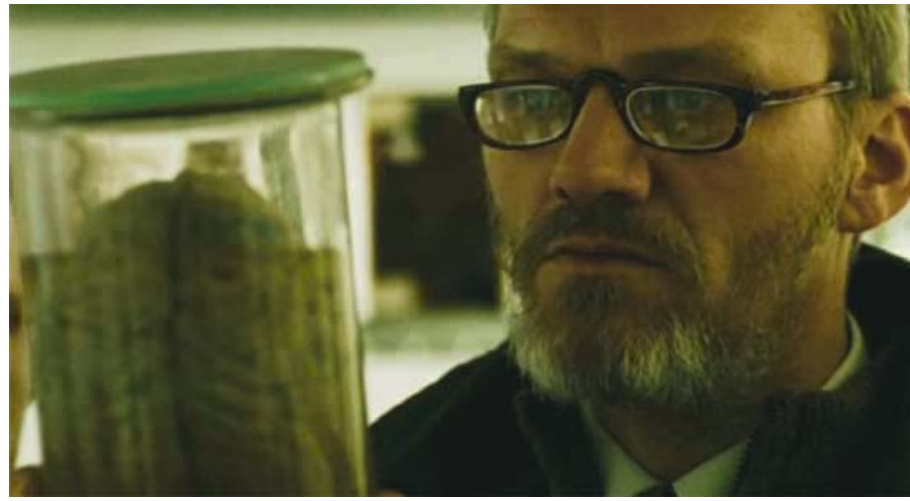

Figure 5. Clone Tommy and his friend smell 'plastic' (Benedek Fliegauf: Womb, 2010).

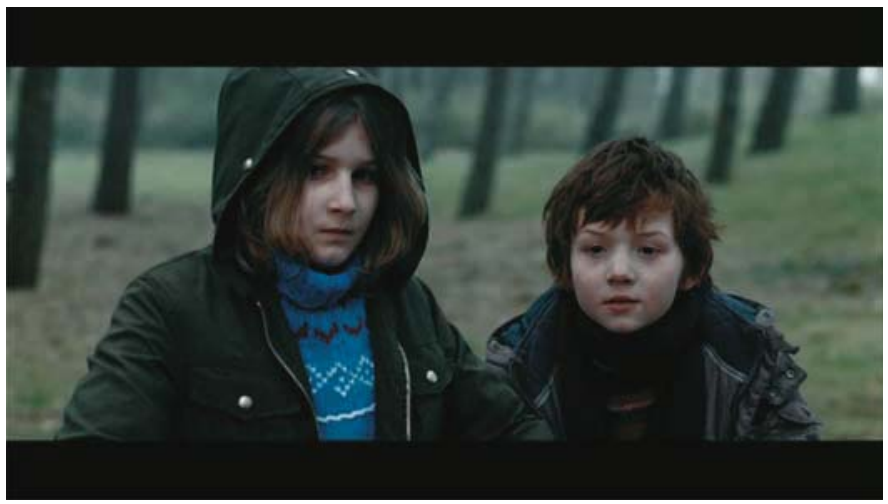

Figure 6. Mother faces clones (Benedek Fliegauf: Womb, 2010).

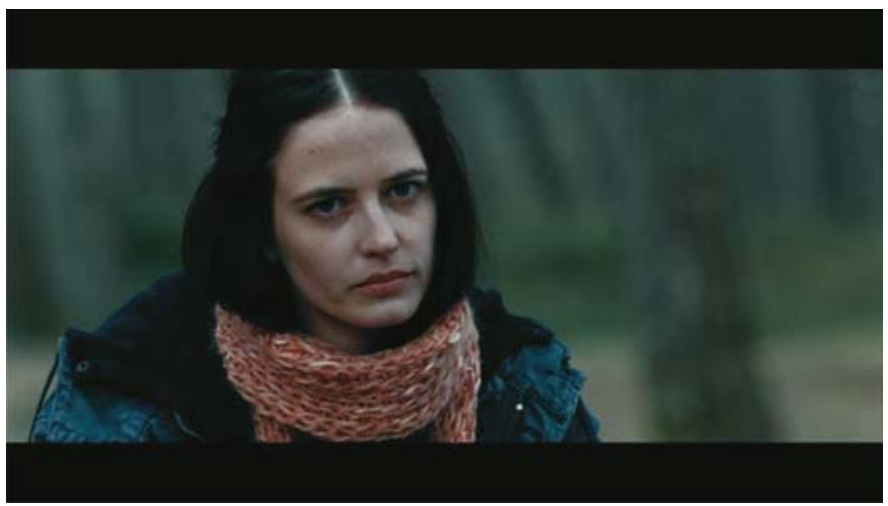


Figure 7. Clone Deema walks away (Benedek Fliegauf: Womb, 2010).

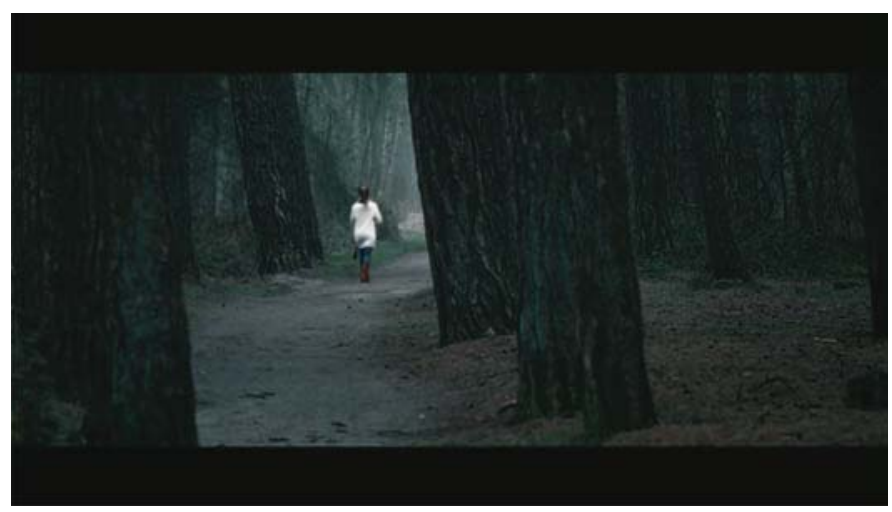

Figure 8. Foundling by Patricia Piccinini (2008), silicon, human hair, polyester, wool, plastic, wire, $41 \times 66 \times 37 \mathrm{~cm}$ (by courtesy of the artist).

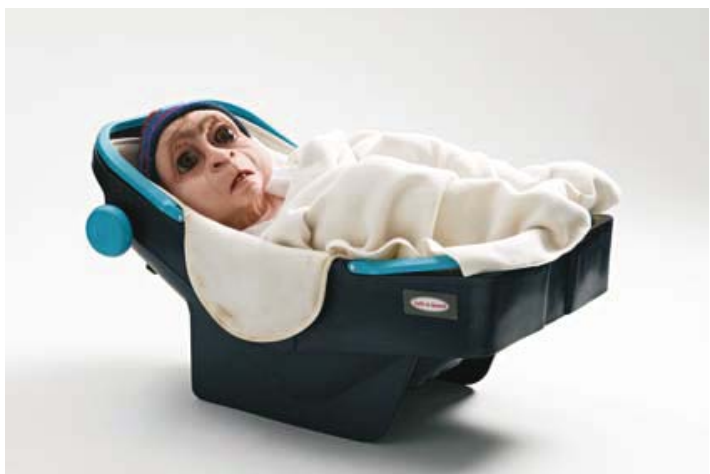

Figure 9. Laura (with Surrogate) by Patricia Piccinini (2006), graphite on paper, $57 \times 77 \mathrm{~cm}$ (by courtesy of the artist).

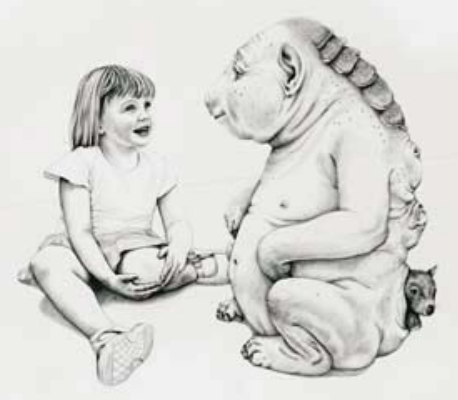


Figure 10. Workshop, 7.00 pm, by Patricia Piccinini (2011), C-Type Photograph, $160 \mathrm{~cm} \times 100 \mathrm{~cm}$ (by courtesy of the artist).

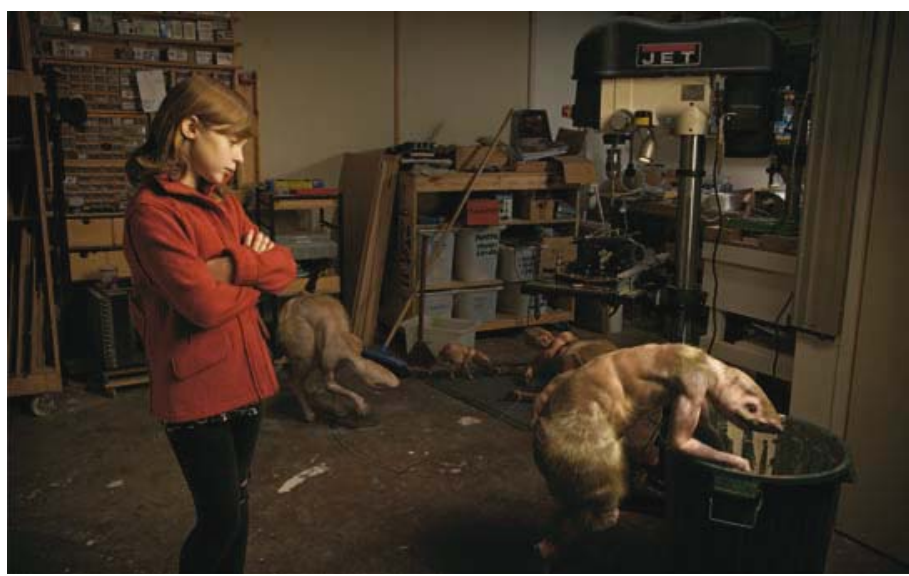

Figure 11. Elsa and creature Dren meet for the first time (Vincenzo Natali: Splice, 2009).

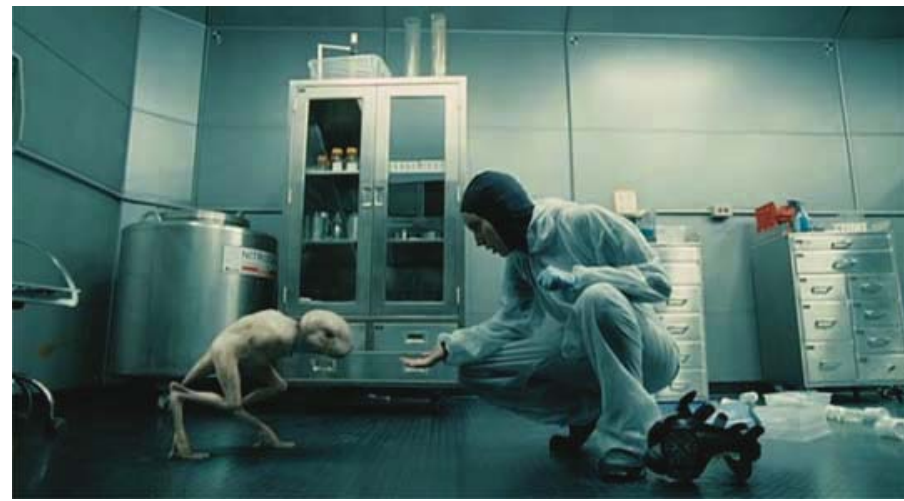

Figure 12. The white rabbit in the clone's arms in Benedek Fliegauf's Womb.

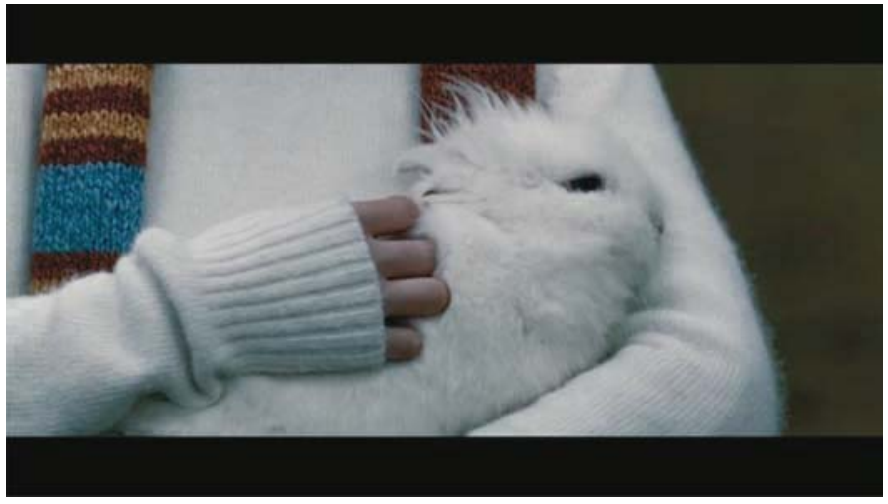

